\title{
A COMPARATIVE STUDY OF CANAGLIFLOZIN (INVOKANA) ON TYPE-I AND TYPE-II DIABETES MELLITUS ON ADULT MALE ALBINO RAT
}

\author{
By \\ Nageh Mabrouk Gabr and Ibrahim Hassan Mohammed* \\ Departments of Medical Physiology and Medical Biochemistry*, Faculty of Medicine, Al- \\ Azhar University \\ E-mail: Gabrnageh@yahoo.com
}

\begin{abstract}
Background: Glycemic control is important in diabetes mellitus to minimize the progression of the disease and the risk of potentially devastating complications. Inhibition of the sodium glucose cotransporter (SGLT2inhibitor) induces glucosuria and has been established as a new anti-hyperglycemic strategy. Canagliflozin is approved as sodium glucose co-transporter 2 inhibitors (SGLT2-inhibitor), plays a distinct and complementing role in glucose homeostasis.
\end{abstract}

Objective: Comparing the effects of Canagliflozin on streptozotocin-induced type-I and type- II- diabetes in adult male albino rat.

Materials and Methods: Sixty male albino rats were randomly categorized into 6 equal groups; Group I (Normal control group): Rats received $2 \mathrm{ml} / 100 \mathrm{~g}$ Na citrate buffer by intraperitoneal injection, Group II (Normal-Canagliflozin-treated-group): Rats received Canagliflozin $(10 \mathrm{mg} / \mathrm{kg} / \mathrm{day}$, orally), Group III (Streptozotocin-induced type-I diabetic group): Rats were subjected to induction of diabetes by a high single intraperitoneal injection of streptozotocin $65 \mathrm{mg} / \mathrm{kg}$ body weight in citrate buffer, Group IV (Streptozotocinnicotinamide- induced type-II diabetic group): The overnight fasted rats were subjected to induction of diabetes by a small single intraperitoneal injection of streptozotocin $40 \mathrm{mg} / \mathrm{kg}$ body weight $(2 \mathrm{ml} / 100 \mathrm{gram})$ in citrate buffer and nicotinamide in a dose of $110 \mathrm{mg} / \mathrm{kg}$ boy weight 15 minutes before streptozotocin injection, Group V (Streptozotocin + Canagliflozin): Received a high dose of streptozotocin $(65 \mathrm{mg} / \mathrm{kg}$ body weight) and Canagliflozin (10 mg/kg/day, orally), and Group VI (Streptozotocin + nicotinamide + Canagliflozin): Received a small dose of streptozotocin $(40 \mathrm{mg} / \mathrm{kg}$ body weight), nicotinamide $(110 \mathrm{mg} / \mathrm{kg}$ body weight), and Canagliflozin $(10 \mathrm{mg} / \mathrm{kg} / \mathrm{day}$, orally). At the end of the experimental period, blood samples were collected for measuring of fasting serum glucose level, insulin level, C-peptide level, total cholesterol, triglycerides (TG), cholesterol- low density lipoproteins (LDL-C), cholesterol-high density lipoproteins (HDL-C), aspartate transaminase (AST), and alanine transaminase (ALT). Histopathological studies of the pancreas were done.

Results: Streptozotocin-induced diabetes mellitus was associated with significant higher levels of serum blood glucose, total cholesterol, TG and cholesterol- LDL-C, AST, and ALT, with significant lower levels of insulin, C-peptide, and HDL-C as compared to the control normal group. Canagliflozin showed significant lower levels of blood glucose, total cholesterol, TG, LDL-C, AST, and ALT, and significant higher levels of insulin, C-peptide, and HDL-C as compared with the diabetic rats. There were insignificant changes also between groups $\mathrm{V}$ and VI in all parameters.

Conclusion: Canagliflozin improved glycemic, lipidemic disturbances, liver enzymes, and have a potent tissue protective and regenerative effects for the pancreas.

Key words: Canagliflozin, Invokana, Streptozotocin, Diabetes mellitus, Hyperlipidemia. 


\section{INTRODUCTION}

Diabetes mellitus is a growing public health and economic problem worldwide because of its possible complications. It is one of the leading causes of death. So, it needs to be treated urgently as hyperglycemia causes multiorgan damage which decreases quality of life (Parveen et al., 2019).

Most patients eventually require therapy intensification with multiple antidiabetic drugs to achieve glycemic control (Olga et al., 2018). For secondline treatment intensification, the American Diabetes Association recommends thiazolidinediones, glucagon-like peptide-1 receptor agonists, sulphonylureas, dipeptidyl peptidase inhibitors, sodium-glucose co-transporter2 (SGLT2) inhibitors or insulin (American Diabetes Association, 2018).

Sodium-dependent glucose cotransporters SGLT1 and SGLT2 are of primary importance for glucose homeostasis by absorbing glucose from the diet in the small intestine (via SGLT1) and by reabsorbing the filtered glucose in the tubular system of the kidney (primarily by SGLT2 and to lesser extent via SGLT1). The latter process returns glucose into the blood stream and prevents urinary glucose loss (Tatiana et al., 2019).

Currently, three SGLT2 inhibitors are available (Canagliflozin, Empagliflozin, and Dapagliflozin) and, are now widely approved antihyperglycemic therapies. Because of their unique glucosuric mechanism (Krishna et al., 2018). Sodium glucose co-transporter 2 inhibitors (Canagliflozin) represent a new class of oral anti-diabetic agents with a novel mechanism that inhibits glucose reabsorption, allowing glucose to be excreted (Zurek et al., 2017).

The present study was a trial to compare the effects of Canagliflozin (Invokana) in type-I and type-II diabetes mellitus on adult male albino rat.

\section{MATERIALS AND METHODS}

Animals and experimental design: This experimental study was performed at Medical Physiology Department, AlAzhar Faculty of Medicine, Cairo. A total of sixty adult male albino rat of a local strain were used in this study ranging in weight from $120-170$ grams and their ages were 8 weeks at the time of the research. The animals were housed under similar standard environmental conditions in suitable cages $(30 \times 42 \times 30 \mathrm{~cm}$ for every 5 rats) with wide meshed raised floors to prevent coprophagia. They were kept ten days on basal diet before starting experimental diet for adaptation. They were also kept at room temperature and normal light/dark cycle. Rats had free access to water and fed on rodent chow diet food all over the period of the work ( 8 weeks) and all investigations were conducted in accordance with the guiding principles for the care and use of research animals and were approved by the Institutional Research Board. Animals were divided randomly and equally into 6 groups as follows:

Group I (Normal control group): Rats received $2 \mathrm{ml} / 100$ gram body weight $\mathrm{Na}$ citrate buffer by intraperitoneal injection daily for 8 weeks.

\footnotetext{
Group II (Normal-Canagliflozin treated group): Rats received Canagliflozin (10 $\mathrm{mg} / \mathrm{kg} / \mathrm{day}$, orally) for 8 weeks (Yin et al., 2012).
} 


\section{A COMPARATIVE STUDY OF CANAGLIFLOZIN (INVOKANA) ON TYPE...}

Group III (Streptozotocin-induced type-I diabetic group): The overnight fasted rats were subjected to induction of diabetes by a high single intraperitoneal injection of streptozotocin $65 \mathrm{mg} / \mathrm{kg}$ body weight $(2 \mathrm{ml} / 100$ gram) in citrate buffer due to instability of streptozotocin in aqueous media (Marcelo et al., 2017).

\section{Group IV (Streptozotocin-} nicotinamide-induced type-II diabetic group): The overnight fasted rats were subjected to induction of diabetes by a small single intraperitoneal injection of streptozotocin $40 \mathrm{mg} / \mathrm{kg}$ body weight dissolved in citrate buffer and nicotinamide $110 \mathrm{mg} / \mathrm{kg}$ body weight 15 min before STZ injection (Madkor et al., 2011).

\section{Group V (Streptozotocin- Canagliflozin} treated group): Received a high dose of streptozotocin (65 mg/kg body weight), and Canagliflozin $(10 \mathrm{mg} / \mathrm{kg} /$ day, orally) for 8 weeks.

\section{Group VI (Streptozotocin - nicotinamide - Canagliflozin treated group): Received a small dose of streptozotocin (40 mg/kg body weight), nicotinamide $110 \mathrm{mg} / \mathrm{kg}$ body weight 15 min prior to STZ injection, and Canagliflozin (10 mg/kg/day, orally) for 8 weeks.}

Chemicals: After two weeks of acclimatization, the diabetes induced by Streptozotocin powder provided by Nile Pharmaceutical Company, Egypt. Streptozotocin was intraperitoneally (I.P.) administered in doses of 65 and $40 \mathrm{mg} / \mathrm{Kg}$ dissolved in citrate buffer. Control rats received I.P. citrate buffer (Madkor et al., 2011).
Canagliflozin (Invokana; $300 \mathrm{mg}$ ) tablets were purchased from Nile Pharmaceutical Company, Egypt. Each white tablet contained $118 \mathrm{mg}$ lactose as an inactive ingredient. The tablets were crushed, dissolved in distilled water and given orally in a dose of $10 \mathrm{mg} / \mathrm{kg} /$ day (Yin et al., 2012).

Nicotinamide purchased from Nile Pharmaceutical Company, Egypt. It dissolved in $10 \% \mathrm{NaCl}$ solution.

Isoflurine (Nile Pharmaceutical-Egypt) for anesthesia.

\section{Induction of type-I diabetes mellitus: A} single intraperitoneal dose of $65 \mathrm{mg} / \mathrm{kg}$ body weight of streptozotocin dissolved in citrate buffer was used immediately after preparation (Omolaoye et al., 2017).

\section{Induction of type-II diabetes mellitus:} In addition to nicotinamide, a single intraperitoneal dose of $40 \mathrm{mg} / \mathrm{kg}$ body weight of streptozotocin dissolved in citrate buffer was used immediately after preparation (Gautam et al., 2018).

The development of hyperglycemia in rats was confirmed by fasting serum glucose (FBG) estimation after 2 days of STZ injection. The animals that maintained fasting serum glucose higher than $200 \mathrm{mg} / \mathrm{dl}$ were considered diabetic and selected for studies. After Induction of diabetes mellitus, rats were given glucose $10 \%$ (3 $\mathrm{g} / \mathrm{kg}$ body weight) by gastric intubation after 6 hours of STZ administration for the next 48 hours to all diabetic rats to overcome fatal hypoglycemia caused by transient hyperinsulinemia due to partial destruction of beta cells (Wang et al., 2017). 
Rats with serum glucose over 400 $\mathrm{mg} / \mathrm{dl}$ were treated with 2-3 units of mixtard 30 insulin every other day in order to avoid development of ketoacidosis and coma. This dose of insulin did not correct hyperglycemia. Insulin treatment was discontinued 3 days prior to sample collection (Omolaoye et al., 2017).

Blood Sampling: At the end of experiment, fasting rats were lightly anesthetized by isoflurine and venous blood samples were withdrawn from the retro-orbital plexus by heparinized capillary tubes, and rapidly set to the centrifugator at 5000 rotations per minute for 15 minutes. Serum was separated and stored at $-20{ }^{\circ} \mathrm{C}$ till used for determination of serum glucose, insulin, C-peptide (Vivian et al., 2014), lipid profile (Sloan et al., 2012), AST, and ALT levels (Kaveh et al., 2017).

At the end of the experimental period and under isoflurine anesthesia, abdomen of the animal was opened after reaching the stage of surgical anesthesia, as evident by loss of withdrawal reflex. Pancreas was excised for histopathological studies. Pancreatic specimens were preserved in Bouin's solution, then transferred to $70 \%$ alcohol and preserved till used. Paraffin blocks were then made for the tissue samples and different sections were obtained and slides were stained with hematoxyline and eosin ( $\mathrm{Hx}$ and $\mathrm{E})$ stains and examined using a light microscope.

\section{Statistical Analysis:}

Data input and analysis were done using SPSS version 16 computer program. All results were expressed as the mean \pm SD. Statistical comparisons between different groups were done using one-way analysis of variance (ANOVA) followed by the Tukey-Kramer multiple comparison test to judge the difference between various groups. Significance was considered at $\mathrm{P} \leq 0.05$.

\section{RESULTS}

The mean \pm standard deviation of fasting serum glucose was $85.5 \pm 8.96$, $85.3 \pm 5.40,285.1 \pm 26.59, \quad 211.7 \pm$ $36.89,112 \pm 8.64$ and $102.6 \pm 6.6 \mathrm{mg} / \mathrm{dl}$ in groups I, II, III, IV, V and VI respectively. Diabetes induced by streptozotocin (type-I and type-II) resulted in a significant elevation in the levels of fasting serum glucose (FBG) in groups III and IV (diabetic group) in respect to control group I. while the treatment with Invokana reduced the elevated fasting blood glucose significantly in groups $\mathrm{V}$ and IV respectively in respect to untreated streptozotocin-induced diabetic groups. Also, Groups V and IV that are treated with Invokana respectively showed insignificant difference in fasting serum glucose levels changes in respect to each other (Table 1).

The mean \pm standard deviation of serum insulin was $35.2 \pm 3.25,33.02 \pm$ $2.81,6.68 \pm 2.07,8.83 \pm 1.82,17.23 \pm$ 2.16 and $16.69 \pm 2.08 \mathrm{ng} / \mathrm{ml}$ in groups I, II, III, IV, V, and VI respectively. Diabetes induced by streptozotocin resulted in a significant reduction in the levels of insulin in groups III and IV 


\section{A COMPARATIVE STUDY OF CANAGLIFLOZIN (INVOKANA) ON TYPE...}

(diabetic groups) in respect to control group I. while the treatment with Invokana elevated the reduced insulin significantly in groups $\mathrm{V}$ and VI respectively in respect to diabetic groups (groups III and IV). Groups V and VI that are treated with Invokana respectively showed insignificant difference in insulin levels in respect to each other (Table 1).

The mean \pm standard deviation of $\mathrm{C}$ peptide was $33.0 \pm 0.25,31.03 \pm 2.79$, $6.66 \pm 2.05, \quad 8.81 \pm 2.80,18.21 \pm 2.14$, $33.20 \pm 6.7,20.67 \pm 2.04 \mathrm{ng} / \mathrm{dl}$ in groups I, II, III, IV, V, and VI respectively. Diabetes induced by streptozotocin resulted in a significant reduction in the levels of insulin in group III and IVV (diabetic groups) in respect to control group I. while the treatment with Invokana treatment elevated the reduced insulin significantly in groups $\mathrm{V}$ and VI respectively in respect to diabetic group. Groups V and VI that are treated with Invokana respectively showed insignificant difference in insulin levels in respect to each other (Table 1).

The mean \pm standard deviation of serum total cholesterol was140.9 \pm 5.88 , $131.50 \pm 6.54,205.7 \pm 11.83,209.6 \pm$ $44.48, \quad 152.3 \pm 12.06$ and $144.03 \pm 5.60$ $\mathrm{mg} / \mathrm{dl}$ in groups I, II, III, IV, V, and VI respectively. The mean \pm standard deviation of triglycerides (TG) was 100.2 $\pm 11.35,90.3 \pm 10.45,107.7 \pm 10.48$, $102.2 \pm 10.26,97.8 \pm 12.96$ and $99.5 \pm$ $9.01 \mathrm{mg} / \mathrm{dl}$ in groups I, II, III, IV, V, VI and VII respectively. While the mean \pm standard deviation of LDL-C was $80.86 \pm$ $8.16,87.84 \pm 4.52,146.61 \pm 9.78,138.76$ $\pm 45.24,97.9 \pm 8.55$ and $95.8 \pm 8.35$ $\mathrm{mg} / \mathrm{dl}$ in groups I, II, III, IV, V, VI and VII respectively. Diabetes resulted in a significant elevation in the levels of total serum cholesterol, triglycerides and LDL-
$\mathrm{C}$ in group II (diabetic group) in respect to control group I. Treatment with pioglitazone, exendin-4 and combined treatment significantly decreased the total serum cholesterol, triglycerides and LDLC levels when compared to group II. Groups VI and VII showed insignificant changes in total cholesterol, triglycerides and LDL-C in respect in respect to each (Table 1).

The mean \pm standard deviation of HDL-C was $41.2 \pm 5.83,42.5 \pm 2.27$, $75.01 \pm 7.2,69.6 \pm 5.48,42.4 \pm 3.01$ and $39.8 \pm 0.83 \mathrm{mg} / \mathrm{dl}$ in groups I, II, III, IV, V, VI and VII respectively. Diabetes resulted in a significant reduction in the levels of HDL-C in groups III and I (diabetic groups) in respect to control group I. Treatment with Invokana significantly elevated HDL levels when compared to diabetic group. Groups V and VI that are treated with Invokana showed insignificant changes in HDL in respect to each other (Table 1).

The mean \pm standard deviation of AST was $39.6 \pm 3.10,41.1 \pm 7.12,91.02 \pm$ $0.22,83.4 \pm 6.30,46.2 \pm 3.20$ and $47.1 \pm$ $0.37 \mathrm{U} / \mathrm{L}$ in groups I, II, III, IV, V, and VI respectively. The mean \pm standard deviation of ALT was $30.7 \pm 5.45,30.9 \pm$ $7.03,49.30 \pm 2.10,56.7 \pm 9.01,44.6 \pm$ $5.43,40.9 \pm 5.56$ and $30.74 \pm 0.88 \mathrm{U} / \mathrm{L}$ in groups I, II, III, IV, V, and VI respectively. Diabetes resulted in a significant elevation in the levels of AST and ALT in groups III and IV (diabetic groups) in respect to control group I. Treatment with Invokana significantly decreased the AST and ALT levels when compared to groups III and IV. Groups V and VI that were treated Invokana respectively showed insignificant changes in AST and ALT in respect in respect to each other (Table 1) 
NAGEH MABROUK GABR et al.,

Table (1): Effects of Canagliflozin on diabetes, lipid profile, and liver function in different groups (Mean \pm SD)

\begin{tabular}{|c|c|c|c|c|c|c|}
\hline Groups & Group I & Group II & Group III & Group IV & Group V & Group VI \\
\hline \multirow{2}{*}{$\begin{array}{l}\text { Fasting serum } \\
\text { glucose } \\
\text { (mg/dl) }\end{array}$} & $85.5 \pm 8.96$ & $85.3 \pm 5.40$ & $\begin{array}{c}285.1 \pm \\
26.59\end{array}$ & $\begin{array}{c}211.7 \pm \\
36 . .89\end{array}$ & $112 \pm 8.64$ & $102.6 \pm 6.6$ \\
\hline & & $\mathrm{P}>0.05^{*}$ & $\begin{array}{c}\mathrm{P}<0.05^{*} \\
\mathrm{P}<0.05 \text { ® }\end{array}$ & $\begin{array}{l}\mathrm{P}<0.05^{*} \\
\mathrm{P}<0.05 \neq\end{array}$ & $\begin{array}{l}\mathrm{P}<0.05^{*} \\
\mathrm{P}>0.05 @ \\
\mathrm{P}<0.05 \Omega\end{array}$ & $\begin{array}{c}\mathrm{P}<0.05^{*} \\
\mathrm{P}<0.05 ? \\
\mathrm{P}<0.05 \Phi\end{array}$ \\
\hline \multirow[b]{2}{*}{$\begin{array}{l}\text { Insulin } \\
\text { (?IU / ml) }\end{array}$} & $35.2 \pm 3.25$ & $\begin{array}{c}33.02 \pm \\
2.81^{\mathrm{a}} \\
\end{array}$ & $6.68 \pm 2.07$ & $8.83 \pm 1.82$ & $\begin{array}{c}17.23 \pm \\
2.16\end{array}$ & $16.69 \pm 2.08$ \\
\hline & & $\mathrm{P}>0.05^{*}$ & $\begin{array}{c}\mathrm{P}<0.05^{*} \\
\mathrm{P}<0.05{ }^{\circledR}\end{array}$ & $\begin{array}{l}\mathrm{P}<0.05^{*} \\
\mathrm{P}>0.05 \neq\end{array}$ & $\begin{array}{l}P<0.05^{*} \\
P>0.05 @ \\
P<0.05 \Omega\end{array}$ & $\begin{array}{c}\mathrm{P}<0.05^{*} \\
\mathrm{P}<0.05 ? \\
\mathrm{P}<0.059\end{array}$ \\
\hline \multirow[b]{2}{*}{$\begin{array}{c}\text { C-Peptide } \\
\text { level } \\
\text { (ng/dl) }\end{array}$} & $33.0 \pm 0.25$ & $31.03 \pm 2.79$ & $6.66 \pm 2.05$ & $8.81 \pm 2.80$ & $18.21 \pm 2.14$ & $20.67 \pm 2.04$ \\
\hline & & $\mathrm{P}>0.05^{*}$ & $\begin{array}{c}\mathrm{P}<0.05^{*} \\
\mathrm{P}<0.05{ }^{\circledR}\end{array}$ & $\begin{array}{l}\mathrm{P}<0.05^{*} \\
\mathrm{P}>0.05 \neq\end{array}$ & $\begin{array}{l}\mathrm{P}<0.05^{*} \\
\mathrm{P}>0.05 @ \\
\mathrm{P}<0.05 \Omega\end{array}$ & $\begin{array}{l}\mathrm{P}<0.05^{*} \\
\mathrm{P}<0.05 ? \\
\mathrm{P}<0.054\end{array}$ \\
\hline \multirow{2}{*}{$\begin{array}{c}\text { Total } \\
\text { cholesterol } \\
(\mathrm{mg} / \mathrm{dl})\end{array}$} & $140.9 \pm 5.88$ & $\begin{array}{c}131.50 \pm \\
6.54\end{array}$ & $\begin{array}{c}205.7 \pm \\
11.83\end{array}$ & $\begin{array}{c}209.6 \pm \\
44.48\end{array}$ & $\begin{array}{c}152.3 \pm \\
12.06\end{array}$ & $\begin{array}{c}144.03 \pm \\
5.60\end{array}$ \\
\hline & & $\mathrm{P}>0.05^{*}$ & $\begin{array}{c}\mathrm{P}<0.05^{*} \\
\mathrm{P}<0.05 \AA\end{array}$ & $\begin{array}{l}\mathrm{P}<0.05^{*} \\
\mathrm{P}>0.05 \neq\end{array}$ & $\begin{array}{l}\mathrm{P}<0.05^{*} \\
\mathrm{P}>0.05 @ \\
\mathrm{P}<0.05 \Omega\end{array}$ & $\begin{array}{c}\mathrm{P}<0.05^{*} \\
\mathrm{P}>0.05 ? \\
\mathrm{P}<0.05\end{array}$ \\
\hline \multirow[b]{2}{*}{$\begin{array}{c}\mathrm{TG} \\
(\mathrm{mg} / \mathrm{dl})\end{array}$} & $\begin{array}{c}100.2 \pm \\
11.35\end{array}$ & $\begin{array}{c}90.3 \pm \\
10.45\end{array}$ & $\begin{array}{c}107.7 \pm \\
10.48\end{array}$ & $\begin{array}{c}102.2 \pm \\
10.26\end{array}$ & $\begin{array}{l}97.8 \pm \\
12.96\end{array}$ & $99.5 \pm 9.01$ \\
\hline & & $\mathrm{P}>0.05^{*}$ & $\begin{array}{c}P>0.05^{*} \\
P<0.05 \AA\end{array}$ & $\begin{array}{l}\mathrm{P}<0.05^{*} \\
\mathrm{P}>0.05 \neq\end{array}$ & $\begin{array}{c}P<0.05^{*} \\
\mathrm{P}>0.05 @ \\
\mathrm{P}>0.05 \Omega\end{array}$ & $\begin{array}{c}\mathrm{P}<0.05^{*} \\
\mathrm{P}>0.05 ? \\
\mathrm{P}<0.05 \mathrm{I}\end{array}$ \\
\hline \multirow[b]{2}{*}{$\begin{array}{l}\text { LDL-C } \\
(\mathrm{mg} / \mathrm{dl})\end{array}$} & $80.86 \pm 8.16$ & $\begin{array}{c}87.84 \pm \\
4.52\end{array}$ & $\begin{array}{c}146.61 \pm \\
9.78\end{array}$ & $\begin{array}{l}138.76 \pm \\
45.24\end{array}$ & $97.9 \pm 8.55$ & $\begin{array}{c}95.8 \pm \\
88.35\end{array}$ \\
\hline & & $\mathrm{P}>0.05^{*}$ & $\begin{array}{c}\mathrm{P}>0.05^{*} \\
\mathrm{P}<0.05 \AA\end{array}$ & $\begin{array}{l}\mathrm{P}<0.05^{*} \\
\mathrm{P}<0.05 \neq\end{array}$ & $\begin{array}{l}\mathrm{P}<0.05^{*} \\
\mathrm{P}>0.05 @ \\
\mathrm{P}>0.05 \Omega\end{array}$ & $\begin{array}{c}\mathrm{P}<0.05^{*} \\
\mathrm{P}<0.05 ? \\
\mathrm{P}<0.05 \Phi\end{array}$ \\
\hline \multirow[b]{2}{*}{$\begin{array}{l}\text { HDL-C } \\
(\mathrm{mg} / \mathrm{dl})\end{array}$} & $41.2 \pm 5.83$ & $42.5 \pm 2.27$ & $75.01 \pm 7.2$ & $69.6 \pm 5.48$ & $42.4 \pm 3.01$ & $39.8 \pm 0.83$ \\
\hline & & $\mathrm{P}>0.05^{*}$ & $\begin{array}{l}\mathrm{P}>0.05^{*} \\
\mathrm{P}<0.05{ }^{\circledR}\end{array}$ & $\begin{array}{l}\mathrm{P}<0.05^{*} \\
\mathrm{P}>0.05 \neq\end{array}$ & $\begin{array}{l}P<0.05^{*} \\
\mathrm{P}>0.05 @ \\
\mathrm{P}>0.05 \Omega\end{array}$ & $\begin{array}{c}\mathrm{P}<0.05^{*} \\
\mathrm{P}>0.05 ? \\
\mathrm{P}<0.05 \mathrm{I}\end{array}$ \\
\hline \multirow[b]{2}{*}{$\mathrm{AST}(\mathrm{U} / \mathrm{L})$} & $39.6 \pm 3.10$ & $41.1 \pm 7.12$ & $91.02 \pm 0.22$ & $83.4 \pm 6.30$ & $46.2 \pm 3.20$ & $48.1 \pm 0.37$ \\
\hline & & $\mathrm{P}>0.05^{*}$ & $\begin{array}{c}\mathrm{P}>0.05^{*} \\
\mathrm{P}<0.05{ }^{\circledR}\end{array}$ & $\begin{array}{l}\mathrm{P}<0.05^{*} \\
\mathrm{P}>0.05 \neq\end{array}$ & $\begin{array}{l}P<0.05^{*} \\
P>0.05 @ \\
P>0.05 \Omega\end{array}$ & $\begin{array}{l}\mathrm{P}<0.05^{*} \\
\mathrm{P}>0.05 ? \\
\mathrm{P}<0.05 \mathbb{}\end{array}$ \\
\hline \multirow[b]{2}{*}{$\operatorname{ALT}(\mathrm{U} / \mathrm{L})$} & $30.7 \pm 5.45$ & $30.9 \pm 7.03$ & $49.30 \pm 2.10$ & $56.7 \pm 9.01$ & $44.6 \pm 5,43$ & $40.9 \pm 4.56$ \\
\hline & & $\mathrm{P}>0.05^{*}$ & $\begin{array}{c}\mathrm{P}>0.05^{*} \\
\mathrm{P}<0.05{ }^{\circledR}\end{array}$ & $\begin{array}{l}\mathrm{P}<0.05^{*} \\
\mathrm{P}>0.05 \neq\end{array}$ & $\begin{array}{l}\mathrm{P}<0.05^{*} \\
\mathrm{P}>0.05 @ \\
\mathrm{P}<0.05 \Omega\end{array}$ & $\begin{array}{c}\mathrm{P}<0.05^{*} \\
\mathrm{P}<0.05 ? \\
\mathrm{P}<0.05 \mathrm{I}\end{array}$ \\
\hline
\end{tabular}

Number of rats in each group $=10$.

@ Group V was compared to group IV., *All groups were compared to control group I., $\Omega$ Group V was compared to group II., \# Group IV was compared to group III., II Group VI was compared to group I, ® Group III was compared to group II., ? Group VI was compared to group II. 


\section{A COMPARATIVE STUDY OF CANAGLIFLOZIN (INVOKANA) ON TYPE...}

In control groups (group 1), the pancreatic acini appeared rounded, lined by pyramidal cells with deep basal basophilic cytoplasm and apical acidophilic cytoplasm. Their nuclei were basally located and vesicular. The acini were surrounding the paler well separated islets of Langerhans. They were nearly oval in outline and formed of cords of cells and separated by blood capillaries. The cells were polygonal in shape, have a light basophilic cytoplasm with central vesicular nuclei (Figure 1).

In nromal group received invokana, histological sections of pancreatic tissue were nearly similar to that of the control group, as regard to the acini surrounding the islets of Langerhans (Figure 2).

All sections of type-I diabetic group showed loss of the cord arrangement, the cells of the islets showed many signs of degeneration and necrosis in the form of vacuolated cytoplasm and swollen nuclei, vacuolated cytoplasm with karyolytic or karyorrhectic nuclei, dark eosinophilic vacuolated cytoplasm with karyolytic or karyorrhectic nuclei, dark eosinophilic cytoplasm with pyknotic nuclei. Loss of cells was also seen (Figure 3 ). On the other hand, there were more or less similar changes in pancratic tissues in type IIdiabetic groups (group IV) in the form of some loss of the cord arrangement, less degeneratin and necrosis pf the cytoplasm amd loss of some clls also seen (Figure 4). In type-I diabetic group treated with Invokana (groups5), islets of Langarhans appeared nearly similar to that of control group. They were well separated from the surrounding acini. Some islets showed the normal cord like arrangement of the islet cells and regained the normal architecture of the islet. Few cells showed pykontic nuclei with dark eosinophilic cytoplasm. The blood capillaries were congested and dilated. Signs of degeneration and necrosis in the form of vacuolated cytoplasm and swollen nuclei, vacuolated cytoplasm with karyolytic or karyorrhectic nuclei, dark eosinophilic cytoplasm with pyknotic nuclei markedly decreased with mild variations between the three groups (Figure 5).

In type-2 diabetic group treated with Invokana (group V), islets of Langarhans appeared nearly similar to that of control group. They were well separated from the surrounding acini. Some islets showed the normal cord like arrangement of the islet cells and regained the normal architecture of the islet. Few cells showed pykontic nuclei with dark eosinophilic cytoplasm (Figure 6). 


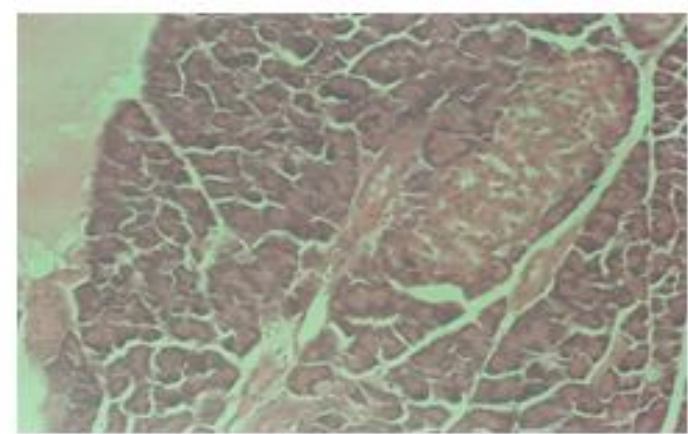

Figure (1): A section of pancreas obtained from control group I showed normal acini surrounding the islets of Langerhans ( $\mathrm{H} \& \mathrm{E}$ $\mathrm{x} 500$ ).

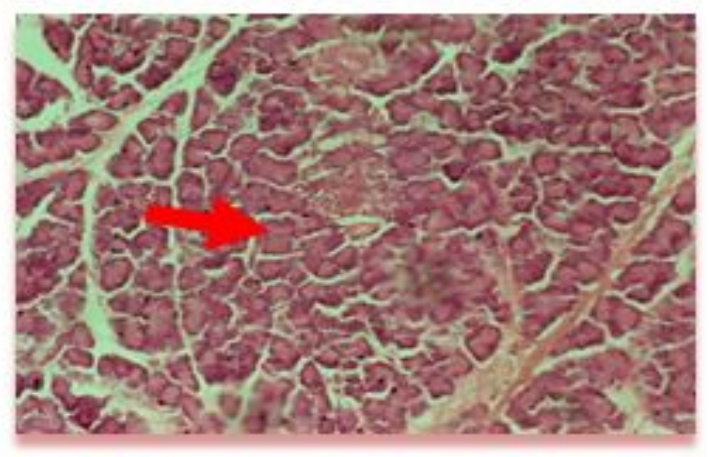

Figure (2): A a section of pancreas from control group II showed miminal congestion of the acini surrounding the cord arrangement of islets of Langerhans (Red arrow)(H \& E $\mathrm{x} 500$ ).

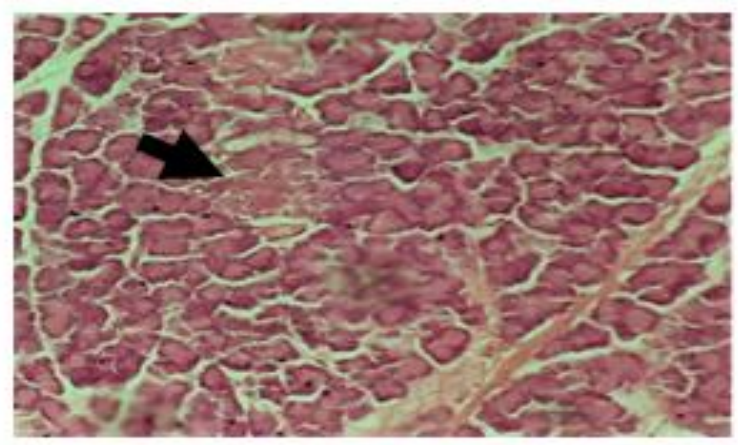

Figure (3): A section of pancreas from the type-1 diabetic group (H\&E x1000) showed loss of the normal islets architecture. The cells showed mild to moderate degenerative changes in the form of vacuolated cytoplasm.

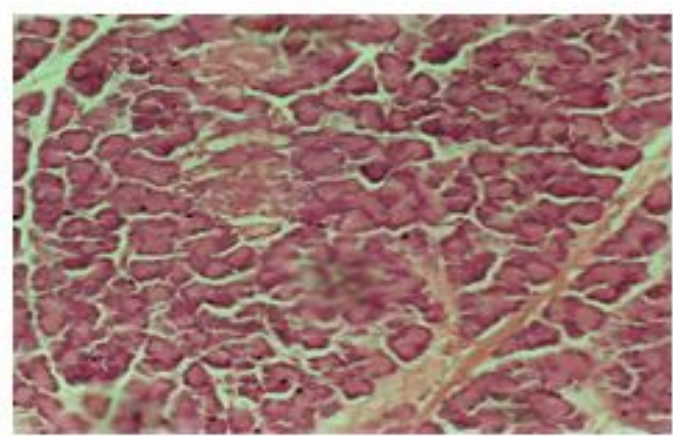

Figure (4): A pancreatic tissue in group IV $(\mathrm{H}$ \& $\mathrm{E} \times 500$ ) showed loss of the normal islets architecture. The cells showed vacuolated cytoplasm with mild degeneration.

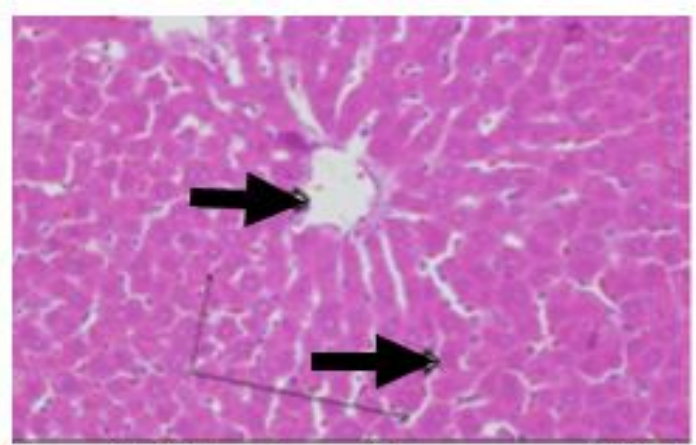

Figure (5): A sections of the pancreas (H \& E $x$ 500) from type-I diabetic group treated with Invokana showedmild showed mild atrophy of the $\beta$-cell of the pancreatic Islets of Langerhans. There is minimal noticed $\beta$-cell improvement (Black arrows).

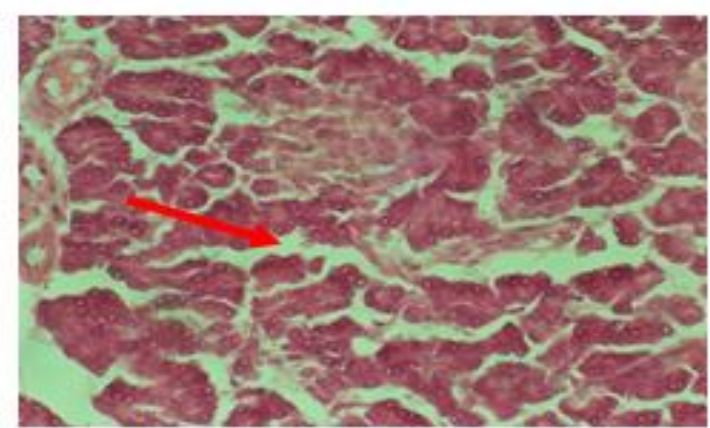

Figure (6): Sections of the pancreas (H \& E $x$ 500) from type-II diabetic group treated with Invokana showed mild atrophy of the $\beta$ cell of the pancreatic Islets of Langerhans. There is minimal noticed $\beta$-cell improvement (Red arrow). 


\section{A COMPARATIVE STUDY OF CANAGLIFLOZIN (INVOKANA) ON TYPE...}

\section{DISCUSSION}

Despite there are available effective and well-tolerated treatments of diabetes, still many patients could not attain recommended glycemic level (Chaudhury et al., 2017). Complementary medicine can offer novel, safe, and cost-effective options for regulating serum glucose levels and blood lipid profiles (Hadi et al., 2018). One form of these complementary medicines is the use of herbaceous plants, such as Invokana that have several therapeutic effects such as antiseptic, antispasmodic, diuretic, antibacterial and antidiabetic activities (Iranshahy et al., 2017).

In the present work, type-I diabetes mellitus was induced by a high single intra-peritoneal injection of streptozotocin. Streptozotocin is rapidly uptaken by pancreatic $\beta$-cells causing formation of reactive oxygen species which are responsible for $\beta$-cell damage.

Type-II diabetes mellitus was induced by a small single intra-peritoneal injection of streptozotocin with concurrent administration of nicotinamide to alleviate streptozotocin toxicity on $\beta$-cells (Gokhan et al., 2017). Nicotinamide is an antioxidant which exerts protective effect on the cytotoxic action of STZ by scavenging free radicals. It causes only minor damage to pancreatic $\beta$ - cell mass producing type-II diabetes. Type-II diabetes mellitus characterized by loss of about $60 \%$ of $\beta$ - cell functions (Ranjan et al., 2018).

The present study revealed that intraperitoneal administration of STZ significantly increased fasting serum glucose level with a significant concomitant reduction in serum insulin and C-peptide levels in both diabetic groups type-I \& II when compared with the normal control.

C-peptide is produced in equal amounts to insulin and is the best measure of endogenous insulin secretion in diabetes mellitus. C-peptide is considered a reliable marker of residual $\beta$-cell function in patients with type-I diabetes during the long-lasting process of immune destruction of $\beta$-cells which may assist in differentiating type-I from type-II diabetes (Gokhan et al., 2017).

These results are in agreement with Wang et al. (2017) who reported elevation in glucose level and reduction in insulin level in STZ-induced diabetes by direct cytotoxic action of STZ on the pancreatic $\beta$ - cells.

Adeyi et al. (2012) attributed this increase in glucose levels to the reactive oxygen species induced by streptozotocin. This, in conjunction with a simultaneous massive increase in cytosolic calcium concentrations, caused rapid destruction of pancreatic islet cells, and a concomitant reduction in synthesis/release of insulin and c-peptide.

Sindhuja et al. (2017) had reported that both the SGLT inhibitors Canagliflozin and Empagliflozin possess antioxidant activity. Empagliflozin shows higher efficacy in reducing oxidative stress compared with Canagliflozin. Thus, the inhibitors of sodium-glucose cotransporters type-II (SGLT2) possess additional antioxidant activity, and acts as novel therapy for the management of both types of diabetes mellitus.

Histopathological examination of streptozotocin-treated rats (groups III and 
IV) resulted in loss of the cord arrangement of islets, marked reduction in the size of cellular components of the islet cells along with variable levels of degeneration in the form of vacuolated cytoplasm and swollen nuclei and the appearance of apoptotic cells in group III more than in group IV. Such outcomes were in line with those of Adeyemi et al. (2015) who noted also a significant reduction in the numerical density of islet cells (number/pancreas), islet cell area and diameter, and $\beta$-cell density in diabetic rat.

In the present study, Invokana specifically reduced serum glucose level in both type-I and type-II diabetic rat.

Canagliflozin (Invokana) specifically targets the kidney by blocking the reabsorption of filtered glucose, thus leading to increased urinary glucose excretion, especially when hyperglycemia is present (Abdul-Ghani et al., 2011). This mechanism of action holds promise for patients with type-I and type-II DM in terms of improvements in glycemic control and limited the risk of hypoglycemia (Berhan and Barker, 2013). Normally, up to $180 \mathrm{~g}$ of sugar can be reabsorbed through the kidneys each day without glucose spilling into the urine. SGLT2 inhibitors block approximately $30-50 \%$ of glucose reabsorption in the proximal renal tubule by lowering the renal threshold for glucose that is not lower than $70 \mathrm{mg} / \mathrm{dL}$ resulting in excess glucose excretion in the urine without increasing the risk of hypoglycemia. This mechanism of action is independent upon the presence of endogenous insulin (Ranjan et al., 2018).

There was a significant increase of serum insulin and C-peptide levels in diabetic groups-treated with Invokana (groups V and VI) compared to diabetic groups (groups III and IV).

Kim et al. (2015) concluded that the Invokana can protect $\beta$-cells by reducing its apoptosis, promoting its proliferation and neogenesis. This finding can be explained by activation of phosphoinsitide-3 kinase signaling pathway which has proliferative and anti-apoptotic effect on $\beta$-cells.

Canagliflozin is a weak inhibitor of SGLT1. In other tissues that contribute to glucose homeostasis, including the small intestine, the action of SGLT1 is predominant (Takebayashi et al., 2017). Therefore, establishing the intestinal effects of canagliflozin on glucose homeostasis is very important for this medication as canagliflozin lowers postprandial glucose and insulin levels.

Zurek and his Co-workers (2017) mentioned that Canagliflozin reduces postprandial plasma insulin and C-peptide concentration in healthy subjects by two distinct mechanisms, increasing urinary glucose excretion due to renal SGLT2 inhibition, and delaying oral glucose absorption, which is likely due to transient intestinal SGLT1 inhibition.

Jabbour et al. (2014) concluded that SGLT2 inhibitors use is associated with decreased insulin resistance and increased insulin mediated glucose disposal into the muscles.

Diabetic groups treated with Invokana (groups V and VI) showed that islets of Langerhans appeared nearly similar to that of control group. They were well separated from the surrounding acini. Some islets showed the normal cord like 


\section{A COMPARATIVE STUDY OF CANAGLIFLOZIN (INVOKANA) ON TYPE...}

arrangement of the islet cells and regained the normal architecture of the islet. Few cells showed pykontic nuclei with dark eosinophilic cytoplasm. The blood capillaries were congested and dilated. Signs of degeneration and necrosis markedly decreased with mild to moderate variations between the 2 groups.

The present study revealed that I.P administration of STZ in high dose to induce type-I (group II) or in low dose to induce type-II (group IV) significantly elevate total cholesterol, triglycerides, LDL-C with a significant concomitant reduction in serum HDL-cholesterol in both diabetic untreated groups.

Lipids play a key role in the pathogenesis of diabetes mellitus. Serum lipids are usually high in diabetes mellitus. The abnormal high concentration of serum lipids in the diabetic subjects is due, mainly to the increase in the mobilization of free fatty acids from the peripheral fat depots, since insulin inhibits sensitive lipase. Secondary to absolute (type-I) or relative (type-II) lack of insulin, disturbances in carbohydrate, protein, and fat metabolism occur in diabetes mellitus, which might be reflected by high levels of triglycerides and total cholesterol (Seyedeh et al., 2017).

The current study showed that Invokana treatment reduced serum cholesterol, serum triglycerides, and serum LDL-C level, as well as a significant increase serum HDL-C in diabetic groups treated by Invokana (groups V and VI) when compared to diabetic non treated groups (groups III and IV).
These results were in agreement with Hadi et al. (2018) who reported that Invokana supplementation showed a significant reduction of TC blood concentrations and serum triglycerides in meta-analysis of randomized controlled trials

Nazeam and his Co-workers (2018) were in agreement with these results and mentioned that Canagliflozin was associated with an increase in plasma levels of low-density lipoprotein cholesterol (LDL-C) compared with placebo. This increases in LDL cholesterol also have been noted with other SGLT2 inhibitors, potentially resulting from metabolic changes such as increased lipoprotein lipase activity, but the exact mechanism is unknown (Zurek et al., 2017).

Canagliflozin was associated with increase in HDL cholesterol, and a decrease in triglycerides. An increase in LDL cholesterol was noted with canagliflozin compared with glimepiride (Mori et al., 2016). An increase in LDL cholesterol could show downstream metabolic effects of SGLT2 inhibition and urinary caloric loss (e.g. increased lipoprotein lipase activity leading to increased cholesterol content of LDL cholesterol), and modest hemoconcentration resulting from an osmotic diuretic effect due to glucosuria (similar to what has been reported with other agents with diuretic action) (Mikhail, 2014). However, because the specific mechanism is not precisely known, further investigation is needed to ascertain the mechanism by which SGLT2 inhibition leads to increases in LDL cholesterol. Thus, the effect on LDL 
cholesterol will be better understood with additional planned analyses of fasting lipids (Ranjan et al., 2018).

Plasma AST and/or ALT, are primarily recommended for the assessment of hepato-cellular injury. They are sensitive markers for liver damage, and the elevated activities of these marker enzymes in plasma are indicative of cellular leakage and loss of the functional integrity of cell membranes in the liver (Gurbet et al., 2013).

In the present study, there were significant increases in serum AST and ALT levels in both type-I and type-II induced diabetic group (groups III and IV) when compared to control groups.

The untreated diabetic groups (groups III and IV) exhibited a statistically signi? cant rise in liver enzymes indicating the relationship between diabetes and the incidence of hepato-toxicity. These results agreed with Vagula and his Co-workers (2014) who emphasized that diabetic patients are suffering from hepatic failure compared to patients who do not have diabetes. Some potential explanations for elevated transaminases in diabetic states include oxidant stress from reactive lipid peroxidation.

Elevated liver enzymes can be a sign of non-alcoholic fatty liver disease (NAFLD), a group of conditions that is associated with obesity, hyperglycemia and insulin resistance, and affects about $75 \%$ of patients with diabetes (Leiter et al., 2016). Invokana treatment resulted in significant decreases in serum AST and ALT level in diabetic groups (V and VI) treated with Invokana compared to diabetic groups (groups III and IV).
These results were in consistent with that obtained in a study performed by Leiter et al. (2018) where they found a significant reduction in serum AST and ALT with canagliflozin treatment of diabetic patients.

Canagliflozin besides its control in the blood sugar level, it also improves liver enzymes. Such improvements have been observed in conjunction with improvements in glycemic control and insulin resistance in diabetic (Gautam et al., 2018).

Invokana treatment dramatically controlled elevated levels of AST and ALT in comparison with those in the STZ-challenged group (Park et al., 2018).

Invokana reduced serum AST and ALT level in group $\mathrm{V}$ (type-I) and group IV (type-II) due to anti-inflammatory and immunomodulatory effects (Kaveh et al., 2017).

\section{CONCLUSION}

Canagliflozin (Invokana)) could be used as a supportive therapeutic line in both types of diabetes mellitus because it showed the best results of lowering blood glucose and increasing insulin, and Cpeptide levels. There were remarkable therapeutic effects of this drug in improving hyperlipidemia.

\section{REFERENCES}

1. Abdul-Ghani, M.A., Norton, L. and Defronzo, R.A. (2011): Role of sodiumglucose cotransporter 2 (SGLT 2) inhibitors in the treatment of type 2 diabetes. Endocr. Rev., 32(4):515-31.

2. Adeyemi, D.O., Komolafa, O.A., Adewole, O.S., Obuotor, E.M., Abiodun, A.A. and Adenowo, T.K. (2015): Histomorphological and morphometric studies of the pancreatic islet cells of diabetic rats treated with extract 
of Annonamuricata. Folia Morphol., 69(2): 92-100.

3. Adeyi, A., Idowu, B., Mafiana, C., Oluwalana, S., Ajayi, O. and Akinloye, $O$. (2012): Rat model of food-induced nonobese-type 2 diabetes mellitus: comparative pathophysiology and histopathol-ogy. Intl $\mathrm{J}$ Physiol Pathophysiol Pharmacol., 1:51-8.

4. American Diabetes Association (2018): Diagnosis and classification of diabetes mellitus. Diabetes Care, 39(1): 81-90.

5. Berhan, A. and Barker, A. (2013): Sodium glucose co-transports 2 inhibitors in the treatment of type 2 diabetes mellitus: a metaanalysis of randomized double-blind controlled trials. BMC Endocr. Disord., 13(1):58-59.

6. Chaudhury, A., Duvoor, C., Dendi, V.R., Kraleti, S., Chada, A., Ravilla, R., Marco, A., Shekhawat, N.S., Montales, M.T., Kuriakose, K., Sasapu, A. , Beebe, A., Patil, N., Musham, C.K., Lohani, G.P. and Mirza, W. (2017): Clinical Review of Antidiabetic Drugs: Implications for Type 2 Diabetes Mellitus Management. Front. Endocrinol., 8 (6): 1-12.

7. Gautam, A., Agrawal, P.K., Doneria, J. and Nigam, A. (2018): Effects of Canagliflozin on Abnormal Liver Function Tests in Patients of Type 2 Diabetes with Non-Alcoholic Fatty Liver Disease. Journal of the Association of Physicians of India, 66(1): 62-65

8. Gokhan, Tahir, S.O., Humyra, B., Ozlem, B. and Sebahat, O. (2017): C-peptide Measurement may not be Necessary for Choosing a Treatment Modality in Type 2 Diabetes Mellitus: A Retrospective Analysis C-peptid. Turk. J. Endocrinol. Metab., 21:6871.

9. Gurbet, C., Asij, S., Serdar, K., Sevki A., Orhan, A. and Alaattin, S. (2013): A Comparative Study for the evaluation of two doses of ellagic acid on hepatic drug metabolizing and antioxidant. Bio. Med. Research International, 9: 358945-55.

10. Hadi, A., Pourmasoumi, M., Najafgholizadeh, A., Kafeshani, M. and
Sahebkar, A. (2018): Effect of purslane on blood lipids and glucose: A systematic review and meta $\square$ analysis of randomized controlled trials. Phytotherapy Research, 18: 1-10.

11. Iranshahy, M., Javadi, B., Iranshahi, M., Jahanbakhsh, S.P., Mahyari, S., Hassani, F.V. and Karimi, G. (2017): A review of traditional uses, phytochemistry and pharmacology of Portulaca oleracea L. J Ethnopharmacol., 9(205):158-172.

12. Jabbour, S.A., Hardy, E., Sugg, J. and Parikh, S. (2014): Dapagliflozin is effective as add-on therapy to sitagliptin with or without metformin: a 24-week, multicenter, randomized, double-blind, placebo-controlled study. Diabetes Care, 37: 740-50.

13. Kaveh, M., Eidi, A., Nemati, A. and Boskabady, M.H. (2017): Modulation of lung inflammation and immune markers in asthmatic rats treated by Portulaca Oleracea. A.J.P., 7(5): 409-16.

14. Kim, S.Y., Johnson, M.A., McLeod, D.S., Alexander, T., Hansen, B.C., Lutty, GA. (2015): Neutrophils are associated with capillary closure in spontaneously diabetic monkey retinas. Diabetes; 54: 1534-42

15. Krishna, V.R., Amuthalakshmi, S. and Nalini, C.N. (2018): Validation of a stabilityindicating reverse phase method for determination of canagliflozin API. World Journal of Pharmaceutical Research, 7(3): 459-468.

16. Leiter, L.A., Forst, T., Polidori, D., Balis, D.A., Xie, J. and Sha, S. (2018): Effect of canagliflozin on liver function tests in patients with type 2 diabetes. Diabetes Metab., 42 (1): 25-32.

17. Madkor, H.R., Mansour, S.W. and Ramadan, G. (2011): Modulatory effects of garlic, ginger, turmeric and their mixture on hyperglycaemia, dyslipidaemia and oxidative stress in streptozotocin - nicotinamide diabetic rats. British Journal of Nutrition, 105: 1210-1217.

18. Marcelo, S., Pinheiro, 1., luhara, S,. rodrigues, 1., Eila, S., Neto,1., Rafaianne, Q., Moraes, 1., Thaigra, S,. Soares, 1., 
MadilEine, f., Americo, 1., Kieber, E., Campos, 1., Debora, c., Dama, S. and Gustavo, T. (2017): Effect of Bauhinia holophylla treatment in Streptozotocininduced diabetic rats. Anais da Academia Brasileira de Ciências, 89 (1): 263-272.

19. Mikhail, N. (2014): Safety of canagliflozin in patients with type 2 diabetes. Curr .Drug Saf., 9:127-32.

20. Mori, K., Saito, R., Nakamaru, Y., Shimizu, M., Yamazaki, H. (2016): Physiologically based pharmacokineticpharmacodynamic modeling to predict concentrations and actions of sodiumdependent glucose transporter2 inhibitor canagliflozin in human intestines and renal tubules. Drug Dispos., 37(8):491-506.

21. Nazeam, J.A., El-Hefnawy, H.M., Omran, G. and Singab, A. (2018): Chemical profile and antihyperlipidemic effect of Portulaca oleracea L. seeds in streptozotocininduced diabetic rats. Natural Product Research, 32(12): 1484-1488.

22. Olga, M., Kerenaftali, K., Sudhesh, K., Kamlesh, K. and Sanjoy, K. P. (2018): Addition of or switch to insulin therapy in people treated with glucagon like peptide-1 receptor agonists: A real-world study in 66583 patients. American Diabetes Association J., 8:103-116.

23. Omolaoye, T., Stefan, S., Du, Pl. and Bonelike, S. (2017): Diabetes mellitusinduction: Effect of different streptozotocin doses on male reproductive parameters. Acta Histochemica, 120: 103-109

24. Park, J.E., Lee, J.S., Lee, H.A. and Han, J.S. (2018): Portulaca oleracea L. Extract Enhances Glucose Uptake by Stimulating GLUT4 Translocation to the Plasma Membrane in 3T3-L1 Adipocytes. J. Med. Food, 18: 1-7.

25. Parveen, R., Agarwal, N.B., Kaushal, N., Mali, G. and Raisuddin, S. (2019): Efficacy and safety of canagliflozin in type 2 diabetes mellitus: systematic review of randomized controlled trials. Expert Opin Pharmacother., 9:1-11.
26. Ranjan, D., Sharma, A. and Babu, R. (2018): Saxagliptin and Dapagliflozin for type 2 Diabetes mellitus: A Review. International Journal of Drug Regulatory Affairs, 6(3):24-30.

27. Seyedeh, Z., Moklesur, R., Asmah, R., Saad, A. and Fauziah, O. (2017): The effect of pomegranate fresh juice versus pomegranate seed powder on metabolic indices, lipid profile, inflammatory biomarkers, and the histopathology of pancreatic islets of Langerhans in streptozotocin-nicotinamide-i induced type 2 diabetic Sprague-Dawley rats. BMC Complementary and Alternative Medicine, 17:156-166.

28. Sindhuja, M., muthiah, N.S. and Rajeswari, R. (2017): Comparative efficacy of canagliflozin versus empagliflozin on oxidative stress - in-vitro method. Int $\mathrm{J}$ Pharma Bio Sci., 8(4): (P) 232-236.

29. Sloan, J.H., Siegel, R.W. and Ivanova, Y.T. (2012): A novel high-sensitivity electrochemiluminescence (ECL) sandwich immunoassay for the specific quantitative measurement of plasma glucagon. Clin. Biochem., 45: 1640-1644.

30. Takebayashi, K., Hara, K., Terasawa, T., Naruse, R., Suetsugu, M., Tsuchiya, T. and Inukai, T. (2017): Effect of canagliflozin on circulating active GLP-1 levels in patients with type 2 diabetes: a randomized trial. Endocr. J.., 64(9):923-931.

31. Tatiana, Y., Lulu, C., Weifeng, T., Peter, J., Greasley, K., Helena, P., Susanne, J., Kirill, P., Gabriel, H., David, W., Boulton,Y. and Robert, C. P. (2019): Comparison of the urinary glucose excretion contributions of SGLT2 and SGLT1: A quantitative systems pharmacology analysis in healthy individuals and patients with type 2 diabetes treated with SGLT2 inhibitors. Diabetes Obes. Metab., 1-10.

32. Vagula, M.C., Mastro, M. and Caputo, J. (2014): Cognitive impairment and dementia in Type 2 diabetes mellitus. US Pharm., 39(10): 33-37.

33. Vivian, A.F., Merri, P. and Roberta, H.M. (2014): Complications of Diabetes in Clinical 


\section{A COMPARATIVE STUDY OF CANAGLIFLOZIN (INVOKANA) ON TYPE...}

Practice. Pbl. Springer-Verlag London, limited, (5): 41-43.

34. Wang, N., Zhang, P., Xiao, Y. X., Zhao, Y., Zhang, B., Xin, W. and Wen, Y. (2017): Associations between changes in glucagonlike peptide- 1 and body weight reduction in patients receiving acarbose or metformin treatment. Journal of Diabetes, 9: 728-737.

35. Yin, L., Kenji, A., Kiichiro, U., Matsushita, Y., Kuriyama, C., Martin, T., Du, F., Liu, Y., Xu, J., Conway, B., Conway, J.,
Polidori, D., Ways, K. and Demarest, K. (2012): Effect of Canagliflozin on Renal Threshold for Glucose, Glycemia, and Body Weight in Normal and Diabetic Animal Models. Plos. One, 7 (2): 1-7.

36. Zurek, A.M., Yendapally, R. and Urteaga, E. M. (2017): A Review of the Efficacy and Safety of Sodium-Glucose Cotransporter 2 Inhibitors: A Focus on Diabetic Ketoacidosis. Diabetes Spectr., 30(2): 137-142. 
مقارنة تأثثير عقار الكاناجليفلوزين ( الإنفوكانا ) علي

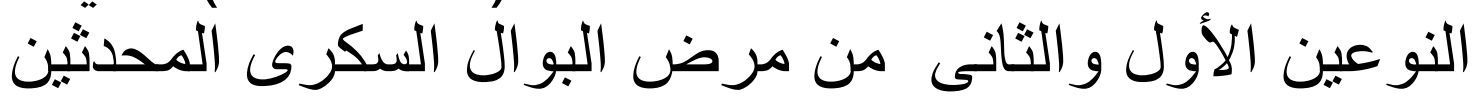

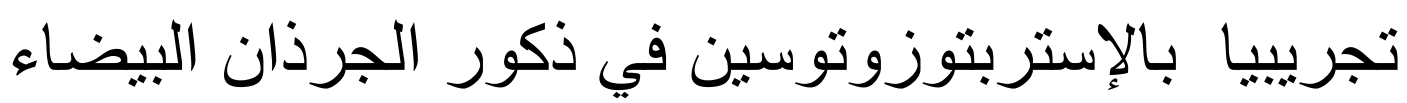
البالغة فيز

\section{ناجح مبروك جبر- إبر اهيم حسن محمد*}

قسمى الفسيولوجيا الطبية والكيمياء الحيوية الطبيةث*، كلية الطب، جامعة الأزهر

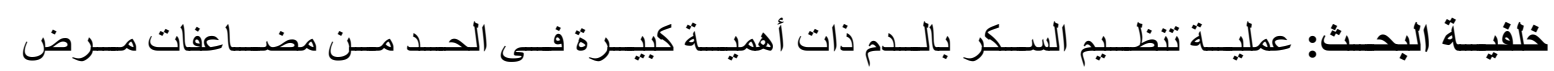

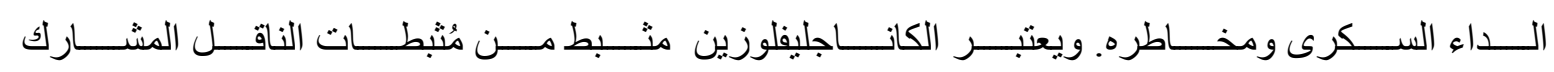

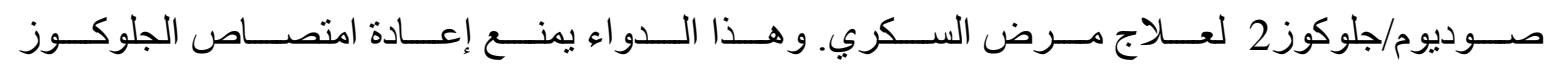

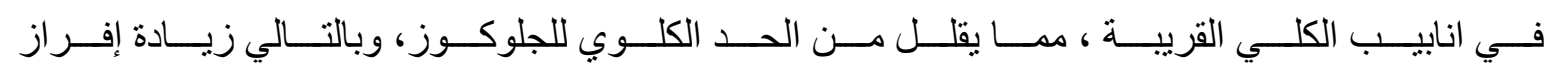

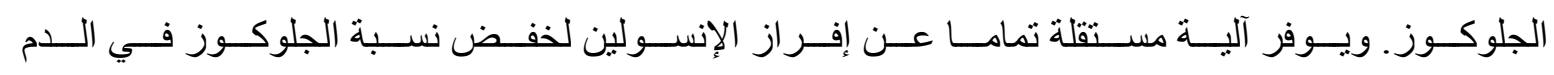
وتحسين التحكم في نسبة السكر في الدم.

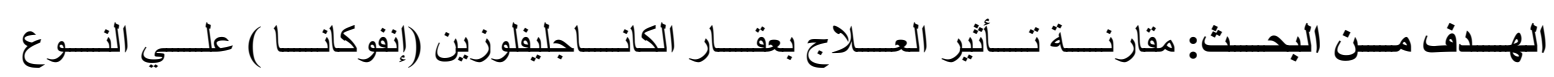

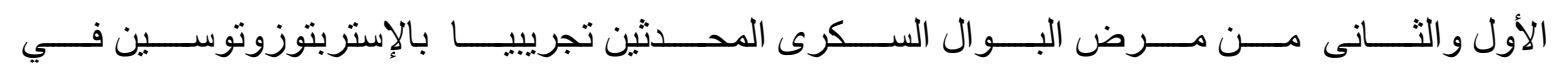

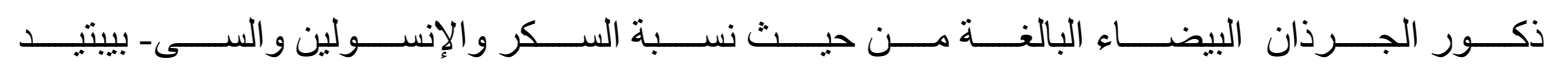
بالبلازما، ووظائف الكبد، و نسبة دلالات الدهون بالدم.

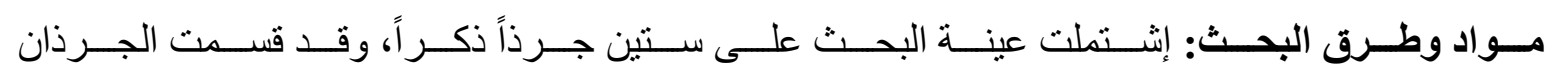
إلى ست مجمو عات متساوية وتم معالجتها كما يلى : لئى

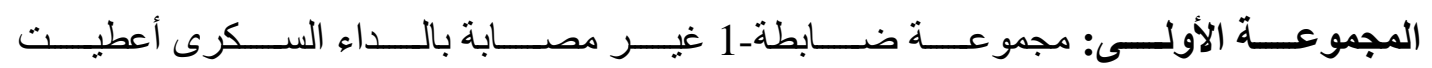
محلول سترات الصوديوم بالحقن داخل التجويف البريتونى يومياً لمدة 8 أسابيع.

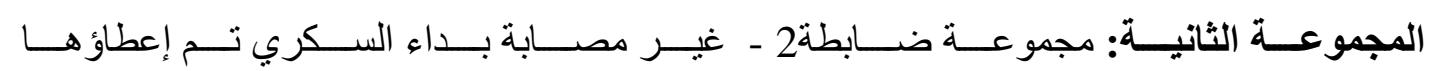
عقار الإنفوكانا بالفم بجرعة 10 ملائ/كجم يومياً لمدة 8 أسابيع.

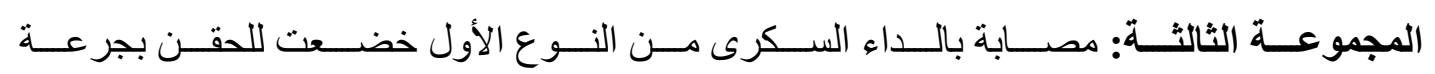
واحدة من الإستربتوزوتوسين في التجويف البريتوني تعادل65 مجم / كجم.

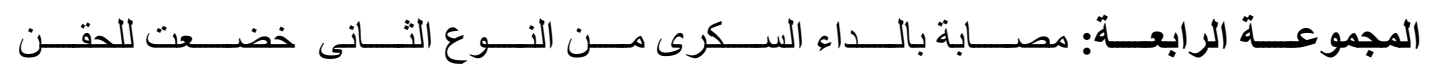

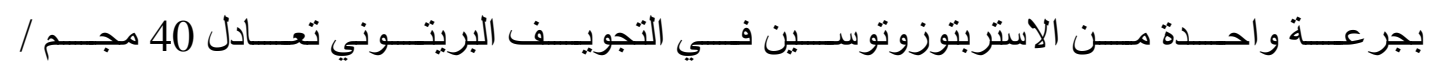




\section{A COMPARATIVE STUDY OF CANAGLIFLOZIN (INVOKANA) ON TYPE...}

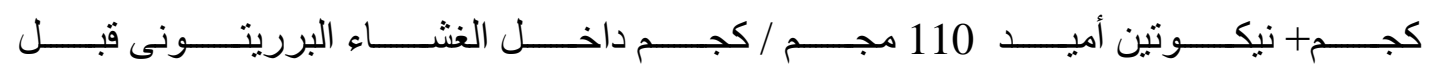
الإستربتوزوتوسين بخمس عشرة دقيقة.

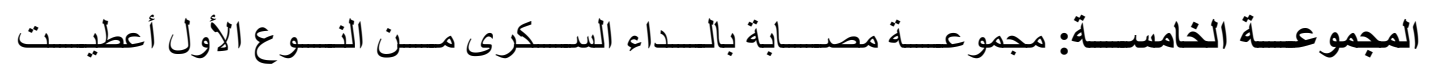

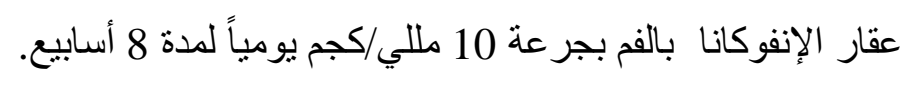

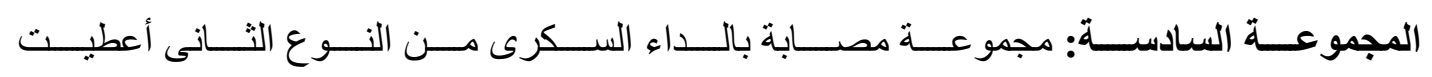
عقار الإنفوكانا بالفم بجر عة 10 مللي/كجم بومياً لمدة 8 أسابيع.

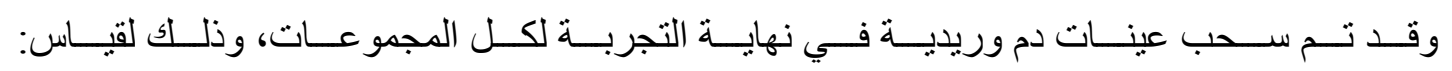

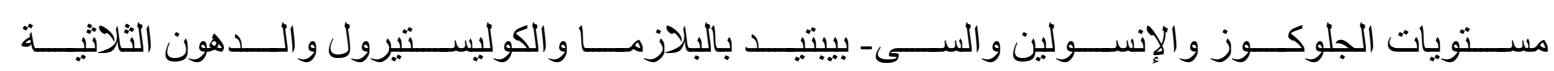

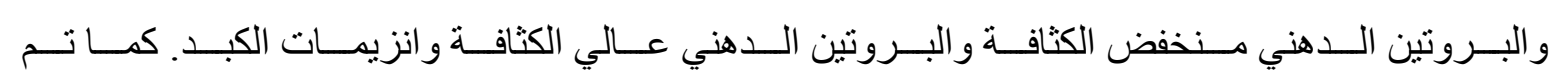
أخذ عينات من البنكرياس للار اسة النسيجية.

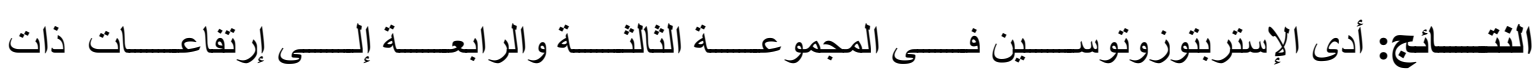

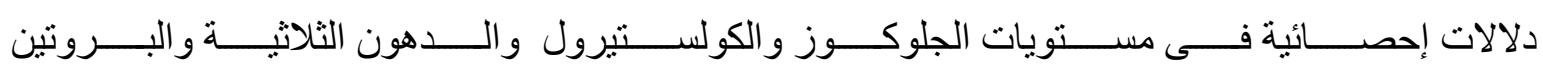

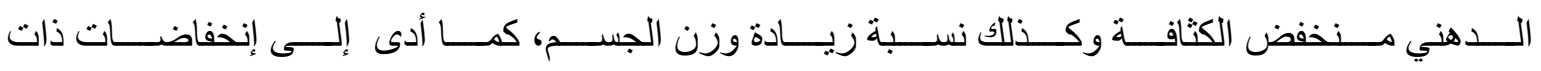

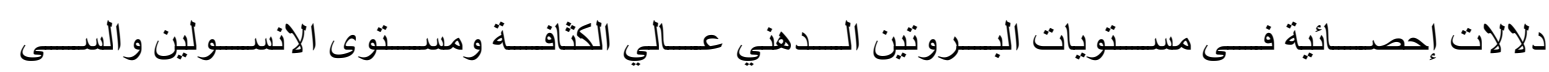

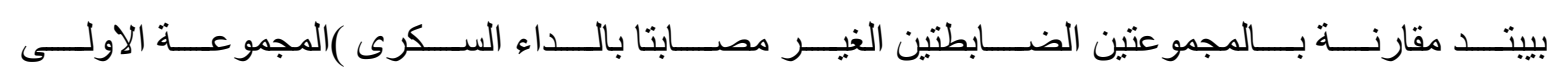

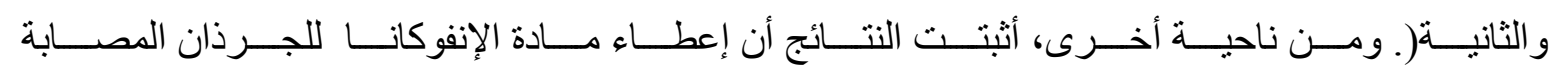

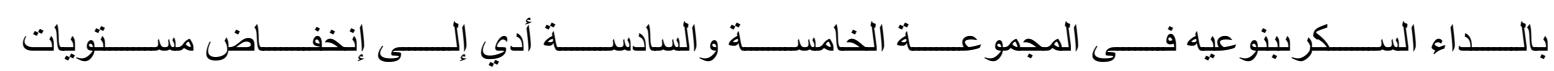

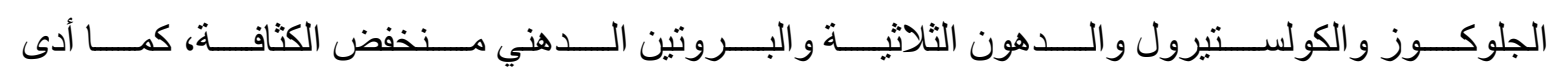

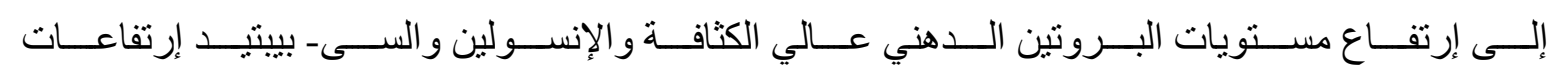

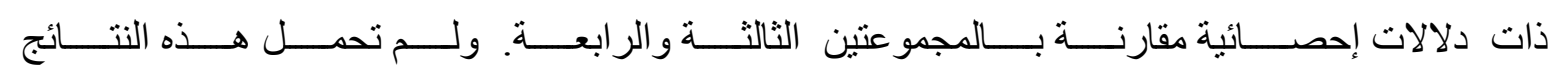

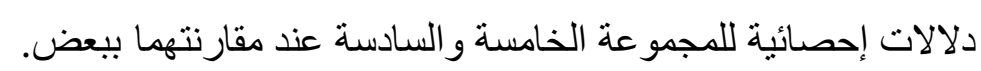

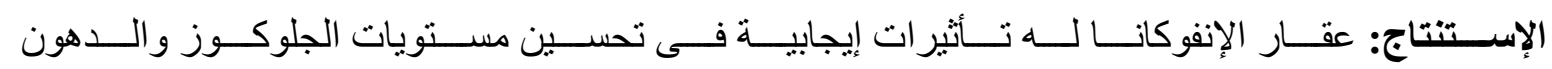

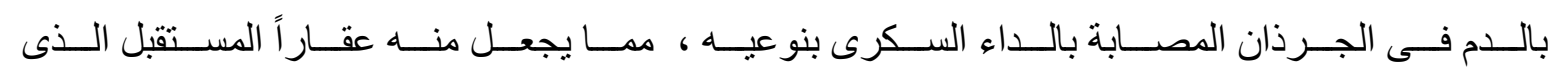

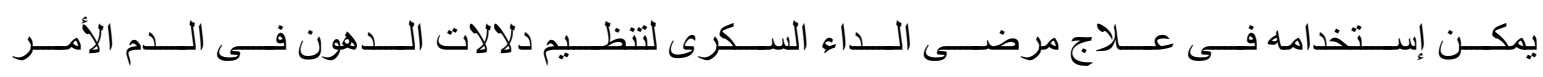

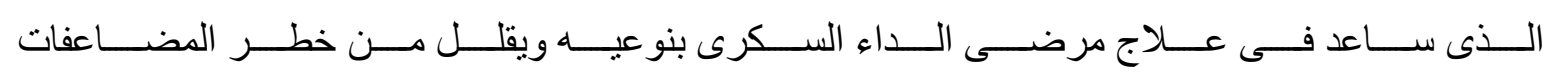
المصحوبة بإرتفاع نسبة الدهون بالدم. 